\title{
Development of the ${ }^{137} \mathrm{Cs},{ }^{90} \mathrm{Sr}$ and ${ }^{3} \mathrm{H}$ Concentrations in the Hydrosphere in the Vicinity of NPP Temelín (South Bohemia)
}

\author{
Eduard Hanslík1 , Diana Marešová1, Eva Juranová1,2, Barbora Sedlářová1 \\ ${ }^{1}$ Department of Radioecology, T. G. Masaryk Water Research Institute, Prague, Czech Republic \\ ${ }^{2}$ Faculty of Science, Institute for Environmental Studies, Charles University, Prague, Czech Republic \\ Email: eduard hanslik@vuv.cz
}

Received 2 July 2015; accepted 9 August 2015; published 12 August 2015

Copyright (C) 2015 by authors and Scientific Research Publishing Inc.

This work is licensed under the Creative Commons Attribution International License (CC BY). http://creativecommons.org/licenses/by/4.0/

(c) (i) Open Access

\section{Abstract}

The paperfocuses on an analysis of the results of long-term monitoring of the concentrations of ${ }^{137} \mathrm{Cs},{ }^{90} \mathrm{Sr}$ and ${ }^{3} \mathrm{H}$ in hydrosphere in the vicinity of Temelín Nuclear Power Plant (Temelín plant). The radionuclides were monitored in surface water, river sediments, aquatic flora and fish species. The main objective of the study was to analyze and integrate all of the knowledge on concentrations and behaviour of these radionuclides, which originate mainly from residual contamination, in order to assess the impacts of Temelín Nuclear Power Plant on hydrosphere in these indicators during its standard operation and possible accidents. The radionuclides were analyzed in terms of spatial and temporal variability in their concentrations and their inflows and outflows, mainly into and from Orlík Reservoir. The analysis included standard radioecological characteristics, which were applicable for assessing long-term development and behavior of radionuclides in the environment affected by their possible accidental releases on the territory of the Czech Republic or outside this territory. For all of the components of the environment, the concentrations of ${ }^{137} \mathrm{Cs}$ and ${ }^{90} \mathrm{Sr}$ which were used for calculation of their effective and ecological half-time, were decreasing. For ${ }^{137} \mathrm{Cs}$ in surface water and fish, the rates of the decrease in the first and second monitoring period were different. The rate of the decrease in ${ }^{90} \mathrm{Sr}$ concentration was invariable. The results of the monitoring showed that $86 \%$ of suspended solids and $62 \%$ of ${ }^{137} \mathrm{Cs}$ inflowing into Orlík Reservoir accumulated in the reservoir while accumulation of ${ }^{90} \mathrm{Sr}$ was not substantiated. Outflows of ${ }^{137} \mathrm{Cs}$ and ${ }^{90} \mathrm{Sr}$ activities were assessed in relation to their concentrations that were accumulated in individual basins until 1986 consequently to Chernobyl accident and tests of atmospheric nuclear weapons. The results for the whole area of the Vltava, Lužnice and Otava River basins upstream from the Vltava River at Solenice showed that during the period $1986-2013$ only $0.49 \%$ of ${ }^{137} \mathrm{Cs}$ activity and $3.6 \%$ of ${ }^{90} \mathrm{Sr}$ activity that accumulated in the basins were washed and flowed out from the area. Distribution coefficients derived from summary analysis of sediments and concentration factors for biota were calculated. Concentrations of ${ }^{3} \mathrm{H}$ in river sites not affected by Temelín plant

How to cite this paper: Hanslík, E., Marešová, D., Juranová, E. and Sedlářová, B. (2015) Development of the ${ }^{137} \mathrm{Cs}$, ${ }^{90} \mathrm{Sr}$ and ${ }^{3} \mathrm{H}$ Concentrations in the Hydrosphere in the Vicinity of NPP Temelín (South Bohemia). Journal of Environmental Protection, 6, 813-823. http://dx.doi.org/10.4236/jep.2015.68074 
were slowly decreasing and their values were substantially below those from the sites affected by the plant.

\title{
Keywords
}

\author{
Caesium 137, Strontium 90, Tritium, Effective Half-Time, Ecological Half-Time, Surface Water, \\ Sediments, Concentration Factor, Distribution Coefficient, Radioecology
}

\section{Introduction}

The study focuses on an analysis of the results of long-term monitoring and assessment of radionuclide concentrations in hydrosphere in the vicinity of Temelín Nuclear Power Plant.

Pilot operation of the Temelín plant was launched in June 2002. Since September 2013, the Temelín plant installed capacity is $2 \times 1055$ MW. Construction and subsequently operation of the Temelín plant initiated implementation of a number of projects, which were focused on possible impacts of the plant on the environment. The length of the series of the data that were monitored during the implementation of the projects was more than 20 years.

During its operation, a nuclear power plant discharges waste waters that contain also radioactive substances, the most important of which is tritium. The waste waters include also other radionuclides, which originate mainly from surface water abstractions and inflows into the plant and minor quantities of these radionuclides originate from standard operation of the plant. The radionuclides that could originate from the plant operation include mainly caesium 137 and strontium 90. These radionuclides of artificial origin were detected in the components of the environment in the vicinity of the Temelín plant also before its operation. This fact is attributed to radionuclide contamination remaining in the environment components after tests of atmospheric nuclear weapons in the fifties and sixties of the 20th century and Chernobyl accident in 1986.

Caesium 137 and strontium 90 are radioecologically important radionuclides, which remain in the environment for a long period of time consequently to their long half-times (30.2 and 28.8 years, respectively). Main attention paid to caesium 137 in the research projects is associated with that fact that concentrations of this radionuclide can be determined from gammaspectrometric analysis, which requires relevant devices, but this determination is less time consuming as compared to radiochemical determination of the strontium 90 falling into beta emitters. This fact explains low availability of data and knowledge concerning concentrations of strontium 90 as compared to other radionuclides not only in the Czech Republic [1]. High attention was paid to tritium originates from the fact that its activities discharged into the environment highly exceed (by several orders of magnitude) those of the other radionuclides.

The main objective of the study was to analyze and integrate all of the knowledge on concentrations and behaviour of these radionuclides, which originated mainly from residual contamination, in order to assess the impacts of the Temelín plant on hydrosphere in these indicators during its standard operation and possible accidents. The analysis included standard radioecological characteristics, which were applicable for assessing longterm development and behaviour of radionuclides in the environment affected by their possible accidental releases on the territory of the Czech Republic or outside this territory.

The analysis of the results of the caesium 137 monitoring uses knowledge from publications of the project team [2]-[8]). The paper also includes an assessment of strontium 90 and tritium concentrations in the Temelín locality, an assessment of outflows of caesium 137 and strontium 90 activities from this territory in relation to their concentrations accumulated consequently to Chernobyl accident, and an assessment of relationships between selected chemical and radioecological characteristics.

\section{Methods}

Concentrations of ${ }^{137} \mathrm{Cs},{ }^{90} \mathrm{Sr}$ and ${ }^{3} \mathrm{H}$ were monitored in surface water (in all substances) and of ${ }^{137} \mathrm{Cs}$ and ${ }^{90} \mathrm{Sr}$ in sediments and complementarily in fish species and aquatic flora. Location of the sampling sites is shown in Figure 1.

The surface water monitoring was launched in 1990 in the Vltava River at Hněvkovice, the Lužnice at 


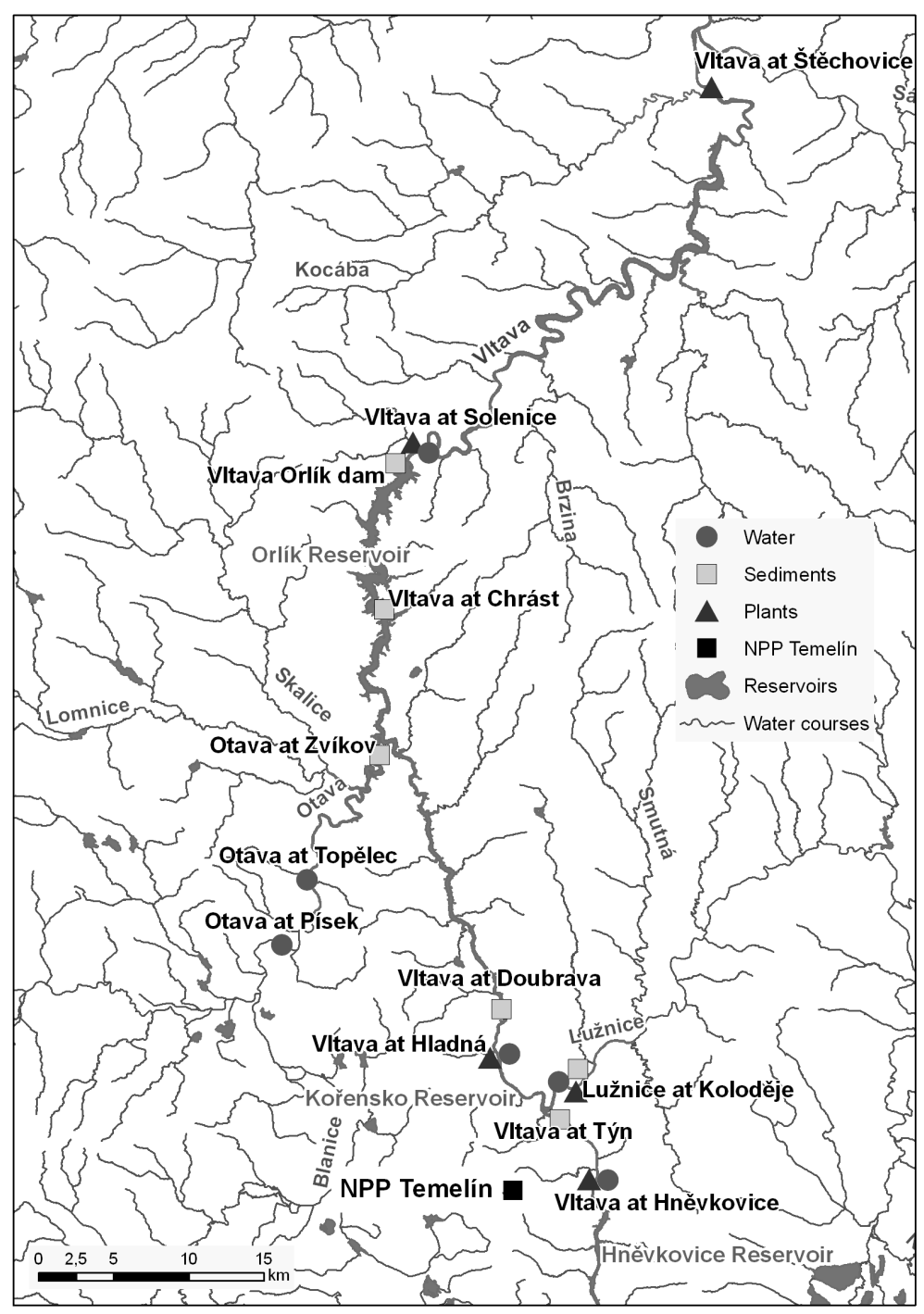

Figure 1. Map of sampling sites.

Koloděje and the Otava at Písek, which are river sites located outside possible impact of the Temelín plant (reference sites), and the Vltava River at Solenice located below the outflows from the plant. Since 1996, the monitoring was also carried out for the Vltava River at Hladná, the site located about $4 \mathrm{~km}$ downstream from the waste water outflow. Frequency of the sampling was 4 samples in a year. Volumes of the water samples were 50 $\mathrm{l}$ for ${ }^{137} \mathrm{Cs}$ and ${ }^{90} \mathrm{Sr}, 0.25 \mathrm{l}$ for ${ }^{3} \mathrm{H}$ and $1 \mathrm{l}$ for suspended solids. The samples for ${ }^{3} \mathrm{H}$ determination were stabilised by cooling while the large-volume samples were stabilised with nitric acid to $\mathrm{pH}$ below 2 . The samples were dried by vaporization at temperature below boiling point and subsequently ignited $\left(350^{\circ} \mathrm{C}\right)$ and closed into the measuring containers. The determination of ${ }^{137} \mathrm{Cs}$ and ${ }^{90} \mathrm{Sr}$ therefore includes all of the substances.

The sediments have been monitored since 1990 with frequency of one sample in a year in the Vltava River below Týn, the Lužnice at Koloděje and the Otava at Zvíkov (reference river sites), and in the Vltava at Doubrava, Chrást and Orlík Reservoir (affected sites). The sediments samples were taken from the top layer (0 - 10 $\mathrm{cm})$.

The fish sampling was carried out by staff of Research Institute for Fishery and Hydrobiology in Vodňany, Vltava River Basin Company and T.G. Masaryk Water Research Institute. The analysis of the results included also those from the monitoring carried out by Faculty of Science of Charles University during the period 19861990, in 1994 and annually since 1998.

The aquatic flora was sampled in the Vltava at Hněvkovice and the Lužnice at Koloděje (reference sites), and 
in the Vltava at Hladná, Solenice and Štechovice (affected sites) with annual frequency in the period 1989-2013. The sampling included littoral species, aquatic mosses, algae species and submerged species.

The solid samples were transported in polyethylene boxes or bags. For the analysis, the samples were dried at $105^{\circ} \mathrm{C}$. The samples of sediments were sieved and their fraction less than $2 \mathrm{~mm}$ was analyzed. The fish samples were disembowelled, weighted, pulped, dried and subsequently powderized and locked in measuring containers. The analyses were performed for dry matter and the results were recalculated for fresh weight. The flora samples were cut into pieces and located into measuring containers.

Gammaspectrometric analysis was applied to determine concentrations of ${ }^{137} \mathrm{Cs}$ by using methods specified in [9] and subsequently the ${ }^{90} \mathrm{Sr}$ concentrations were determined by using a method described in [10]. For determination of tritium activities, methods specified in [11] were used.

Trends in the concentrations of the radionuclides were analyzed by using regression equation in the form:

$$
\ln C_{t}=-\lambda_{\text {eff }} \cdot t+C_{0} .
$$

where $C_{t}$ is radioactivity concentration, $\lambda_{\text {eff }}$ is effective rate of decline in radioactivity concentration, calculated as the slope of decline line (1/y), $t$ is time of the monitoring $(y)$ and $C_{0}$ is natural logarithm of initial concentration.

Statistical significance of the regression line was verified by using Pearson coefficient.

\section{Results and Discussion}

\subsection{Radionuclides in Surface Water}

Concentrations of ${ }^{137} \mathrm{Cs}$ and ${ }^{90} \mathrm{Sr}$ were monitored in all components of surface waters and their trends were assessed by using data from the inflow and outflow into and from Orlík Reservoir. The analyses were performed for subsequent periods 1990-1994 and 1995-2013, and separately for 2001-2013. The analysis of ${ }^{3} \mathrm{H}$ was performed for period 2000-2013.

The highest mean concentrations of ${ }^{137} \mathrm{Cs}$ and simultaneously also its highest activity decline were detected for the Otava River at Písek. In the period 2001-2013, the highest mean ${ }^{137} \mathrm{Cs}$ concentration was derived for the Lužnice River at Koloděje. In the whole period, the lowest ${ }^{137}$ Cs concentrations were detected for the outflow from Orlík Reservoir (the Vltava River at Solenice). For the reservoir, the inflow and outflow ${ }^{137}$ Cs concentrations are compared in Figure 2. Low variability among the river sites were derived for mean concentrations of ${ }^{90} \mathrm{Sr}$. Its minimum values were observed in the Otava River at Písek, maximum values were observed in the Lužnice River at Koloděje. Figure 3 shows the ${ }^{90} \mathrm{Sr}$ concentrations at the inflow and outflow into and from Orlík Reservoir.

During the whole observation period, the concentrations of ${ }^{137} \mathrm{Cs}$ and ${ }^{90} \mathrm{Sr}$ in the tributaries of Orlík Reservoir were in harmony with values observed in other European countries that were affected by radioactive fallout from Chernobyl accident. The examples include data from Finland or ${ }^{137} \mathrm{Cs}$ concentrations in Lago Maggiore

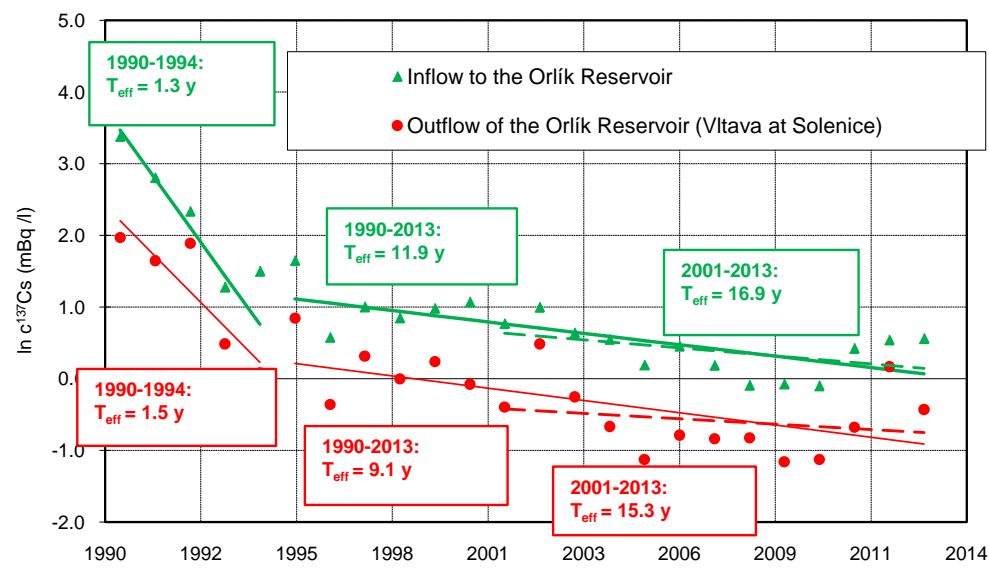

Figure 2. Time changes in annual average ${ }^{137}$ Cs concentrations at the inflow into and outflow from Orlík Reservoir. 


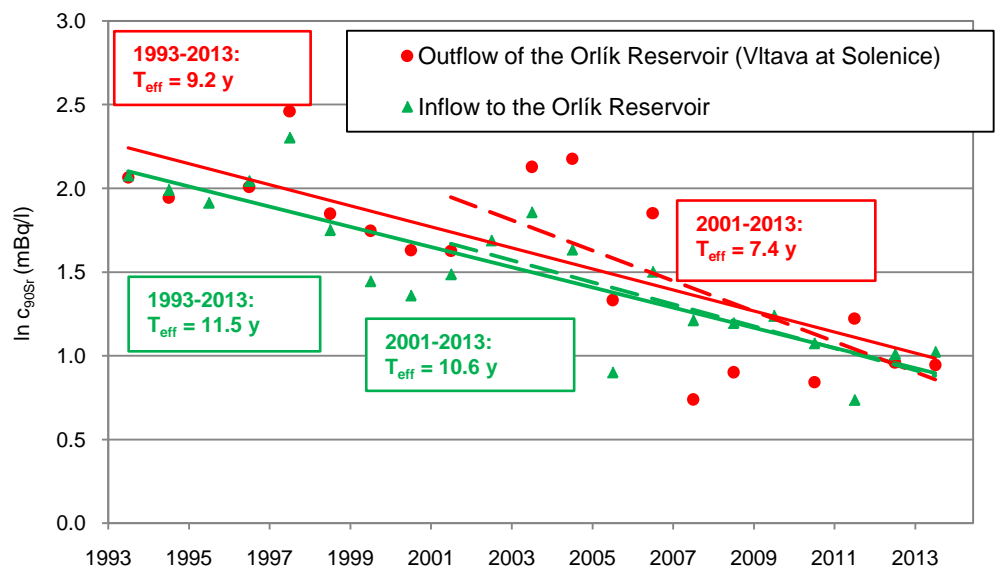

Figure 3. Time changes in annual average ${ }^{90} \mathrm{Sr}$ concentrations at the inflow into and outflow from Orlík Reservoir.

Lake and its tributaries in Italy [12].

The concentrations of ${ }^{137} \mathrm{Cs}$ and ${ }^{90} \mathrm{Sr}$ at the inflow into and outflow from Orlík Reservoir were permanently decreasing during the whole observation period. Between the two analyzedperiods, the rate of the decline expressed by effective half-time of ${ }^{137} \mathrm{Cs}$ decreased from 1.5 - 2.2 years in the period 1990-1994 to 8.2 - 15.4 years in 1995-2013. The decrease continued also during operation of the Temelín plant. The concentrations of ${ }^{90} \mathrm{Sr}$, which have been monitored since 1993, did not exhibit any change in the activity decline. During the whole observation period (1993-2013), the effective half-times were in the range from 8.0 to 11.5 years.

The difference in concentration decline between ${ }^{137} \mathrm{Cs}$ and ${ }^{90} \mathrm{Sr}$ was reported for a number of European rivers. Concentrations of ${ }^{137} \mathrm{Cs}$ in global fallout from Chernobyl accident after the tests of nuclear weapons in the atmosphere exceeded highly those of ${ }^{90} \mathrm{Sr}$. The activities of both radionuclides were rapidly declining in the initial period and this trend continued during the following years for ${ }^{137} \mathrm{Cs}$ while the rate of the ${ }^{90} \mathrm{Sr}$ decline was decreasing. This fact is reflected in lengthening of effective half-time [13]. However, the activities of the radionuclides were decreasing at all river sites also during the operation of the Temelín plant (2001-2013). During this period, the effective half-times of ${ }^{137} \mathrm{Cs}$ ranged between 8.0 and 15.3 years (when the decreasing trend was statistically significant) in the individual river sites, including those affected by the plant. The half-times derived for ${ }^{137} \mathrm{Cs}$ exhibited therefore low spatial variability. The effective half-times of ${ }^{90} \mathrm{Sr}$ ranged in this period between 7.4 and 14.0 years and their mean value for the tributaries of Orlík Reservoir (reference sites) was 10.6 years.

In the whole period, the lowest ${ }^{137}$ Cs concentrations were derived for the outflow from Orlík Reservoir (the Vltava River at Solenice), which is attributable to its biding with suspended solids and their sedimentation in the reservoir. It was derived that $86 \%$ of suspended solids and $62 \%$ of ${ }^{137} \mathrm{Cs}$ inflowing into Orlík Reservoir accumulates in the reservoir. The activities of ${ }^{137} \mathrm{Cs}$ accumulated in Orlík Reservoir were also declining with effective half-time of 9.0 years. Similar ${ }^{137} \mathrm{Cs}$ accumulation was reported for cascade of reservoirs constructed on the Dnepr River [14] or for lakes Lago di Lugano and Lago di Maggiore in Switzerland and Italy. The ${ }^{137}$ Cs concentrations in the upper lake (Lago di Lugano) exceed permanently those in the lower lake (Lago di Maggiore) by one or two orders of magnitude [12]. Accumulation of ${ }^{90} \mathrm{Sr}$ in reservoirs was not substantiated [14]. During some periods, the ${ }^{90} \mathrm{Sr}$ concentrations in reservoirs can even remobilize and outflow from a reservoir, which was substantiated also for Orlík Reservoir, whose mean ratio between the inflow and outflow of ${ }^{90} \mathrm{Sr}$ activities was 0.9 .

Outflows of ${ }^{137} \mathrm{Cs}$ and ${ }^{90} \mathrm{Sr}$ activities were assessed in relation to their concentrations that were accumulated in individual basins until 1986 consequently to Chernobyl accident and tests of atmospheric nuclear weapons. During the period 1990-2013, the annual outflow of ${ }^{137}$ Cs activity from the individual basins did not exceed $1 \%$ of the total activity accumulated in the basin. At the end of this period, the annual outflows in the tributaries of Orlík Reservoir and at the outflow from the reservoir were in the range from $0.002 \%$ to $0.02 \%$. Similarly, [15] reported that in 2005 the outflows from small basins in Austrian Alps ranged between 0.0008\% and 0.0031\% with average of $0.002 \%$. For the whole basin area of the Vltava, Lužnice and Otava Rivers upstream from the 
Vltava River at Solenice, the total outflow of ${ }^{137}$ Cs in the period $1986-2013$ was $0.49 \%$ of the ${ }^{137}$ Cs activity accumulated in the basin, which substantiates that the contribution of the ${ }^{137}$ Cs outflow to the total ${ }^{137}$ Cs reduction in the basin is very small.

The contribution of the ${ }^{90} \mathrm{Sr}$ outflow to its total reduction in the basin exceeds that of ${ }^{137} \mathrm{Cs}$ by approximately one order of magnitude. During the period 1986-2013, the outflow of ${ }^{90} \mathrm{Sr}$ represented 3.6\% of its total accumulation in the basin of the Vltava River at Solenice. This is in harmony with results reported by [16], who concluded that the contribution of the ${ }^{90} \mathrm{Sr}$ outflow exceeds that of the outflow of ${ }^{137} \mathrm{Cs}$ because immobilisation of ${ }^{90} \mathrm{Sr}$ into sediments is much smaller as compared to ${ }^{137} \mathrm{Cs}$ fixation.

In contrast to the results derived for ${ }^{137} \mathrm{Cs}$ and ${ }^{90} \mathrm{Sr}$, the trends in the concentrations of ${ }^{3} \mathrm{H}$ at unaffected (reference) and affected river sites were greatly different. In the period 2000-2013, the mean ${ }^{3} \mathrm{H}$ concentration at the reference sites was $1.1 \mathrm{~Bq} / \mathrm{l}$. Great differences were derived also between the ${ }^{3} \mathrm{H}$ activities at the effected river sites, the Vltava River at Hladná and the Vltava River at Solenice. In addition, both river sites exhibit great difference between values of mean and median calculated from the individual measurements (for the Vltava at Hladná: mean $19.6 \mathrm{~Bq} / \mathrm{l}$, median $2.4 \mathrm{~Bq} / \mathrm{l}$, for the Vltava at Solenice: mean $14.3 \mathrm{~Bq} / \mathrm{l}$, median $11.7 \mathrm{~Bq} / \mathrm{l}$ ). This fact can be explained by high variability in the waste water discharges from the Temelín plant. For the reference sites, the rate of the decline in the ${ }^{3} \mathrm{H}$ concentration was small and below that relevant to the physical half-time, which indicates that significant additional ${ }^{3} \mathrm{H}$ activities originate also from its natural background and tritium produced by nuclear facilities located outside of the territory of the Czech Republic. After subtracting this contamination, statistically significant decreasing trend with effective half time 4.7 years was found only for the profile Vltava at Hluboká.

For all of the assessed radionuclides except for tritium at affected river sites, frequency of values below the minimum detectable activities greatly increased during the last years of the monitored period. The concentrations of these radionuclides are therefore close to measurement limits of the existing methods and analytical devices.

The data on annual discharges of ${ }^{137} \mathrm{Cs},{ }^{90} \mathrm{Sr}$ and ${ }^{3} \mathrm{H}$ at unaffected (reference) and affected river sites were compared with the data provided by Czech Power Works, Temelín Power Plant on discharges of ${ }^{3} \mathrm{H}$ and other activation and fission products (AAFP). The results of a balance assessment of the radionuclides discharged in the Vltava River at Hněvkovice and the Lužnice River at Koloděje in the period 1990-2013 showed that the background activities were relevant to $2.50 \mathrm{GBq} / \mathrm{y}$ for ${ }^{137} \mathrm{Cs}, 8.03 \mathrm{GBq} / \mathrm{y}$ for ${ }^{90} \mathrm{Sr}$ and $1.84 \mathrm{TBq} / \mathrm{y}$ for ${ }^{3} \mathrm{H}$. In the period 2002-2013, the Temelín plant discharged annually 38.8 TBq/y of tritium while maximum annual discharges of other AAFP did not exceed $0.5 \mathrm{GBq} / \mathrm{y}$ [17] [18]). The background activities of ${ }^{137} \mathrm{Cs}$ and ${ }^{90} \mathrm{Sr}$ presently exceed substantially other AAFP discharged from the temelín plant. in the period 2002-2013, the quantity of ${ }^{3} \mathrm{~h}$ discharged in the vltava river at hladná was 7.12 - $229 \mathrm{tbq} / \mathrm{y}$, in average $35.5 \mathrm{tbq} / \mathrm{y}$. in terms of ${ }^{3} \mathrm{~h}$, the impact of the waste water discharges from the temelín plant was therefore substantiated.

\subsection{Radionuclides in Sediments}

The sediment monitoring was focused on concentrations of ${ }^{137} \mathrm{Cs}$ and ${ }^{90} \mathrm{Sr}$. In the whole period, the mean concentration of ${ }^{137} \mathrm{Cs}$ in sediments was $69.2 \mathrm{~Bq} / \mathrm{kg}$ and in 2001-2013, it was $31.3 \mathrm{~Bq} / \mathrm{kg}$. For the whole territory of the Czech Republic, the mean ${ }^{137} \mathrm{Cs}$ concentration in the period 2000-2010 was $14.0 \mathrm{~Bq} / \mathrm{kg}$ [19], which indicates that the sediments in Orlík Reservoir and its tributaries fall into those highly contaminated by ${ }^{137} \mathrm{Cs}$ in the Czech Republic. Mean concentration of ${ }^{90} \mathrm{Sr}$ in the observation period (1993-2013) of $2 \mathrm{~Bq} / \mathrm{kg}$ was substantially below that of ${ }^{137}$ Cs.

In harmony with the results derived for surface water, the concentrations of ${ }^{137} \mathrm{Cs}$ and ${ }^{90} \mathrm{Sr}$ in sediments were decreasing at all monitored sites during the whole observation period, including the years when the Temelínplant was in the operation. The ${ }^{137} \mathrm{Cs}$ effective half-time was 7.5 years or 15.8 years in the period 2001-2013 (Figure 4), which is shorter as compared to that of 23.8 years reported for the period 2000-2010 in [19] as a mean for the sediments on the territory of the Czech Republic. The effective half-time of ${ }^{90} \mathrm{Sr}$ derived from the decreasing trends in the ${ }^{90} \mathrm{Sr}$ concentrations in sediments was 14.7 years. The results show that the effective half-time is gradually increasing similarly to that derived for surface water.

The results of an analysis of ${ }^{137} \mathrm{Cs}$ and ${ }^{90} \mathrm{Sr}$ distribution coefficients between water and sediments showed that the values of $\mathrm{K}_{\mathrm{d} 137 \mathrm{Cs}}$ and $\mathrm{K}_{\mathrm{d} 90 \mathrm{sr}}$ do not exhibit any trends in the observation periods, 1990-2013 ( $\left.{ }^{137} \mathrm{Cs}\right)$ and 1993$2013\left({ }^{90} \mathrm{Sr}\right)$. 


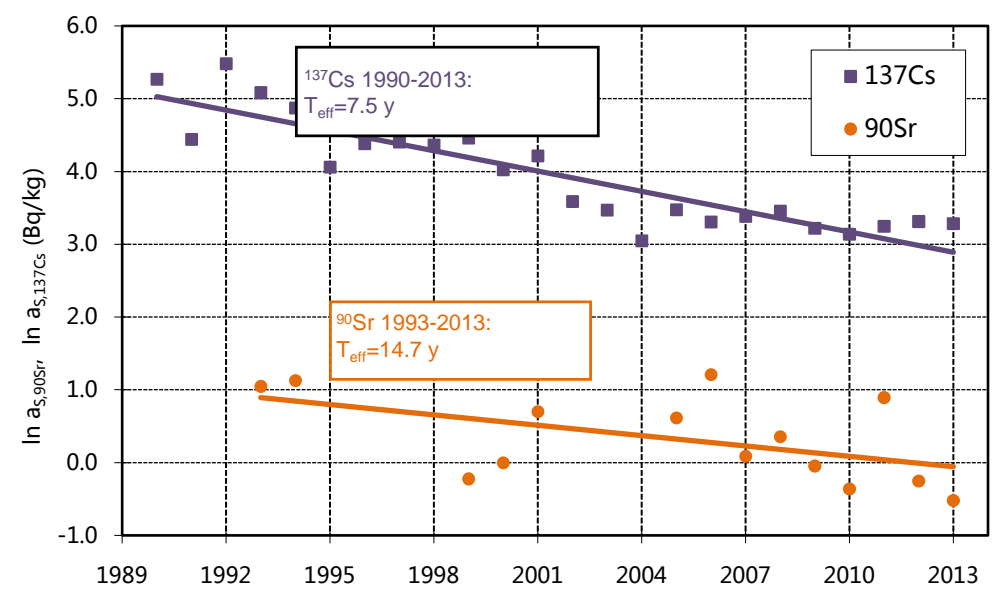

Figure 4. Time changes in annual average concentrations of ${ }^{137} \mathrm{Cs}$ and ${ }^{90} \mathrm{Sr}$ in bottom sediments (dry matter).

The values of the $\mathrm{K}_{\mathrm{d} 137 \mathrm{Cs}}$ coefficients calculated for the individual river sites are in the range from $2.7 \times 10^{2}$ to $1.27 \times 10^{5} \mathrm{l} / \mathrm{kg}$ and their mean value is $2.53 \times 10^{4} \mathrm{l} / \mathrm{kg}$. These results are in harmony with those reported in literature. Reference [20] reported that the best estimate of $\mathrm{K}_{\mathrm{d} 137 \mathrm{Cs}}$ is $8 \times 10^{4} \mathrm{l} / \mathrm{kg}$ and the value of $2.9 \times 10^{4} \mathrm{l} / \mathrm{kg}$ is specified in [21]. The fact that the $\mathrm{K}_{\mathrm{d} 137 \mathrm{Cs}}$ distribution coefficients of sediments in Orlík Reservoir and its tributaries are moderately below those reported can be attributed to different methods that are used for determination of the concentrations of the radionuclides. For this study, the concentrations were determined from all of the water components (both dissolved substances and suspended solids) while the results reported in the literature relate mostly to the concentrations derived from dissolved substances only.

The analysis of the $\mathrm{K}_{\mathrm{d} 90 \mathrm{Sr}}$ coefficients was focused on their integrated assessment for all of the monitored sites. These coefficients calculated for the whole observation period were in the range from 190 to $1770 \mathrm{l} / \mathrm{kg}$ with mean value of $440 \mathrm{l} / \mathrm{kg}$. The $\mathrm{K}_{\mathrm{d} 90 \mathrm{Sr}}$ coefficients are substantially below those that were derived for ${ }^{137} \mathrm{Cs}\left(\mathrm{K}_{\mathrm{d} 137 \mathrm{Cs}}\right)$, which is in harmony with the results reported in literature [20] [21]. They are again smaller as compared to the mean values but still in the range of the individual values reported in the literature. The fact that the ${ }^{90} \mathrm{Sr}$ concentrations were determined from all of the water components in this study plays less important role as compared to that in the ${ }^{137} \mathrm{Cs}$ assessment.

\subsection{Radionuclides in Aquatic Fauna and Flora}

The monitoring of aquatic flora and fish was focused on concentrations of ${ }^{137} \mathrm{Cs}$ and ${ }^{90} \mathrm{Sr}$. The concentrations of ${ }^{137} \mathrm{Cs}$ in fish (related to fresh weight) were assessed for the periods 1986-1990, 1994-2013 and separately for 2001-2013. Between the two periods, the ${ }^{137} \mathrm{Cs}$ concentrations decreased from 2.0 - 47.9 Bq/kg (1986-1990) to $0.05-2.35 \mathrm{~Bq} / \mathrm{kg}$ (1994-2013). With respect to less data availability, the concentrations of ${ }^{90} \mathrm{Sr}$ in fish were assessed for the whole observation period $1990-2013$. For this period the mean ${ }^{90} \mathrm{Sr}$ concentration in fish was 0.6 $\mathrm{Bq} / \mathrm{kg}$. The results of the monitoring and assessment of the ${ }^{137} \mathrm{Cs}$ and ${ }^{90} \mathrm{Sr}$ concentrations in fish are illustrated in Figure 5. The concentrations in the Czech Republic are substantially below those in areas affected by the first radioactive cloud. In the most affected areas in the vicinity of Chernobyl, these activities shortly after the accident were at levels of hundreds of $\mathrm{kBq} / \mathrm{kg}$ and at early nineties still at levels of tens $\mathrm{kBq} / \mathrm{kg}$. The activities of several kBq/kg in this period were reported from Switzerland, England or Germany [22].

Relatively rare data and information on ${ }^{90} \mathrm{Sr}$ concentrations in fish include those by [1], who reported that in the period 1978-1997 the concentrations in the analyzed river species were in the range of $10-17 \mathrm{~Bq} / \mathrm{kg}$, which exceeded the ${ }^{90} \mathrm{Sr}$ concentrations in fish from Orlík Reservoir by approximately one order of magnitude. The concentration levels of ${ }^{90} \mathrm{Sr}$ were however smaller by several orders of magnitude as compared to those of ${ }^{137} \mathrm{Cs}$. Most of the ${ }^{90} \mathrm{Sr}$ activity is accumulated in bones and thus ${ }^{90} \mathrm{Sr}$ is less dangerous than ${ }^{137} \mathrm{Cs}$ in terms of radioactive doses originating from food chain [1].

In harmony with the results derived for surface water, the concentrations of ${ }^{137} \mathrm{Cs}$ and ${ }^{90} \mathrm{Sr}$ in fish exhibited a decreasing trend. In the period 1986-1990, the rapid decrease in ${ }^{137}$ Cs activities was characterized by effective 


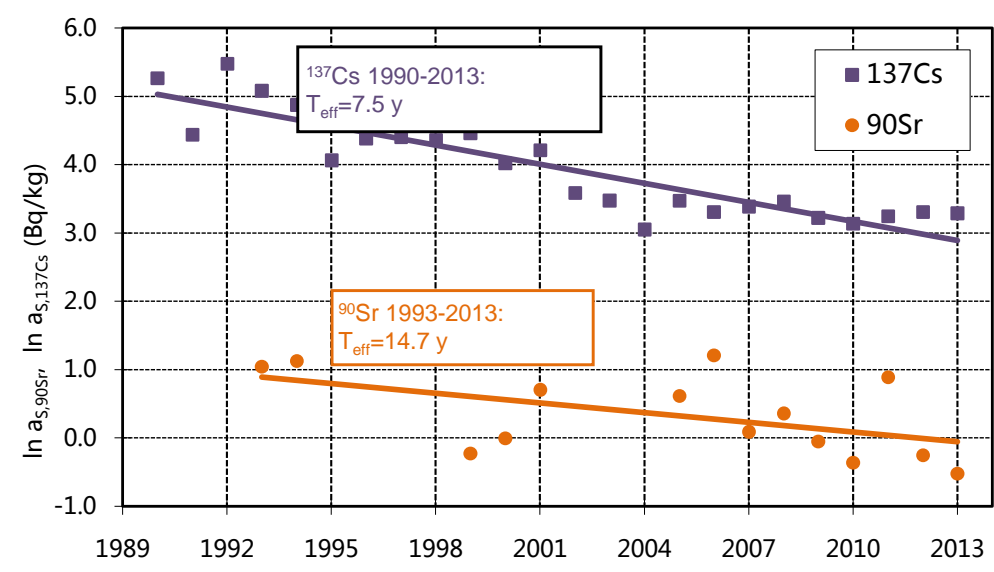

Figure 5. Time changes in annual concentrations of ${ }^{137} \mathrm{Cs}$ and ${ }^{90} \mathrm{Sr}$ in fish (fresh weight).

time-life of 1 year and ecological half-time of 1.1 years. Identical results were reported in[23] from observation in Croatia in the period 1987-1992 while this decrease exceeded that derived by [22] for identical period. The reported half-times are in the range between 2 and 3 years. In harmony with the results from the Czech Republic, the literature sources show that the decrease in the following period was significantly declining towards that expressed by physical half-time. The effective half-times in the Finland lakes were between 3 and 6 years [1], reference [23] reported 5 years for the period 1993-2005, and in Orlík Reservoir, the effective and ecological half-times were 5.1 and 6.1 years, respectively, in the period 1994-2013. The ${ }^{137} \mathrm{Cs}$ half-times that were derived for fish correspond to those derived for water. The decreasing trend continued also during the operation of the Temelín plant.

The half-times reported for ${ }^{90} \mathrm{Sr}$ are substantially longer. The effective half-times derived for several fish species in the Finland lakes were between 7 and 30 years [1]. For fish species in Orlík Reservoir the effective halftime was (9.4 years). The results of ${ }^{137} \mathrm{Cs}$ and ${ }^{90} \mathrm{Sr}$ monitoring of surface water and fish (fresh weight) were used for determination of concentration factors $\mathrm{CF}_{137 \mathrm{Cs}}$ and $\mathrm{CF}_{90 \mathrm{Sr}}$. It was concluded in [1] that concentration factor can be calculated under steady conditions, which occur 8 to 10 years after an accident. For Orlík Reservoir, the $\mathrm{CF}_{137 \mathrm{Cs}}$ values calculated from the period 1986-1990 did not differ significantly from those derived for the period after 1995 and therefore the mean $\mathrm{CF}_{137 \mathrm{Cs}}$ was calculated by using all of the calculated values. Its resulting value was $217 \mathrm{l} / \mathrm{kg}$. The mean $\mathrm{CF}_{137 \mathrm{Cs}}$ value specified in [21] is $3.0 \times 10^{3} \mathrm{l} / \mathrm{kg}$ (the range of the values is $4.5 \times$ $10^{1}-2.4 \times 10^{4}$ ) while the ${ }^{137}$ Cs mean factor calculated for fish species in Orlík Reservoir is smaller by one order of magnitude. All of the calculated values were however in the range reported in [21]. The smaller values of $\mathrm{CF}_{137 \mathrm{Cs}}$ can be explained by several factors, which include small size of the statistical sample, uneven proportion between predatory and unpredatory fish species, the use of both dissolved solids and suspended solidsin surface water for determination of the ${ }^{137} \mathrm{Cs}$ concentration, and also small ${ }^{137} \mathrm{Cs}$ concentrations because the values reported in literature are frequently derived from localities, whose ${ }^{137} \mathrm{Cs}$ activities are higher.

For ${ }^{90} \mathrm{Sr}$, the mean value of the concentration factor $\left(\mathrm{CF}_{90 \mathrm{Sr}}\right)$ was $130 \mathrm{l} / \mathrm{kg}$, which is in approximate harmony with the mean of $1.9 \times 10^{2} \mathrm{l} / \mathrm{kg}$ (range of $2.2 \times 10^{1}-7.1 \times 10^{2} \mathrm{l} / \mathrm{kg}$ ) reported in [19]. Similar results were reported in [18] for lakes in the vicinity Chernobyl (46 - 452) while [1] reported 550 - 1300 l/kg for lakes in Finland.

Concentrations of ${ }^{137} \mathrm{Cs}$ were monitored also for several aquatic flora species (in dried matter). The results substantiated an assumption that the highest ${ }^{137} \mathrm{Cs}$ concentrations are accumulated in a group of aquatic mosses (21.8 Bq/kg in 1996) and algae (17.9 Bq/kg in 1996). A comparison of the results between the river sites unaffected and affected by the outflows from the Temelín plant was complicated by different plants growing at the individual sites with exception of reed species. Since 2006, the monitoring was therefore focused on these species, which were also used for the assessment. The results of the assessment showed, that the concentrations of ${ }^{137} \mathrm{Cs}$ in the reed species were decreasing with effective half-time of 13.4 years. The decreasing trend was identified for unaffected as well as for affected river sites and continued also in the period when the Temelín plant was in the operation. 
The ${ }^{90} \mathrm{Sr}$ concentrations in reed species were in the range between $<0.4$ and $6.1 \mathrm{~Bq} / \mathrm{l}$ (in dried matter) and these concentrations were decreasing with effective half-time of 6.5 years. The results are for ${ }^{137} \mathrm{Cs}$ and ${ }^{90} \mathrm{Sr}$ illustrated in Figure 6.

$\mathrm{CF}_{137 \mathrm{Cs}}$ concentration factors were assessed for the reed species and knotgrass (Polygonumhydropiper) and $\mathrm{CF}_{90 \mathrm{sr}}$ factors for the reed species. The mean values of $\mathrm{CF}_{137 \mathrm{Cs}}$ (recalculated for fresh weight) were $60.7 \mathrm{l} / \mathrm{kg}$ for reed species and $276 \mathrm{l} / \mathrm{kg}$ for the knotgrass, which is in the limits of $1.9 \times 10^{0}-3.3 \times 10^{4} \mathrm{l} / \mathrm{kg}, 9.7 \times 10^{1} \mathrm{l} / \mathrm{kg}$ in average, reported in [21].

The mean $\mathrm{CF}_{90 \mathrm{Sr}}$ value of $17.7 \mathrm{l} / \mathrm{kg}$ (fresh weight) for reed species is in the range (5 - $551 \mathrm{l} / \mathrm{kg}$ ) specified in [20] while [21]) reported higher values $\left(3.9 \times 10^{1}-1.9 \times 10^{3} \mathrm{l} / \mathrm{kg}, 4.1 \times 10^{2} \mathrm{l} / \mathrm{kg}\right.$ in average). It can be concluded that ${ }^{137} \mathrm{Cs}$ and ${ }^{90} \mathrm{Sr}$ bioaccumulation in aquatic flora depends on a number of factors (plant species, seasonality, etc.) and its lower levels as compared to aquatic fauna are attributable to a feeding level [20].

\section{Summary}

For all of the components of the environment, the concentrations of ${ }^{137} \mathrm{Cs}$ and ${ }^{90} \mathrm{Sr}$, which were used for calculation of their effective and ecological half-times, were decreasing. For ${ }^{137} \mathrm{Cs}$ in surface water and fish, the rates of the decrease in the first and second monitoring period were different. The rate of the decrease in ${ }^{90} \mathrm{Sr}$ concentration was invariable. The results of the monitoring showed that $86 \%$ of suspended solids and $62 \%$ of ${ }^{137} \mathrm{Cs}$ inflowing into Orlík Reservoir accumulated in the reservoir while accumulation of ${ }^{90} \mathrm{Sr}$ was not substantiated. Outflows of ${ }^{137} \mathrm{Cs}$ and ${ }^{90} \mathrm{Sr}$ activities were assessed in relation to their concentrations that were accumulated in individual basins until 1986 consequently to Chernobyl accident and tests of atmospheric nuclear weapons. The results for the whole area of the Vltava, Lužnice and Otava River basins upstream from the Vltava River at Solenice showed that during the period $1986-2013$ only $0.49 \%$ of ${ }^{137} \mathrm{Cs}$ activity and $3.6 \%$ of ${ }^{90} \mathrm{Sr}$ activity that accumulated in the basins were washed and flowed out from the area. Distribution coefficients derived from summary analysis of sediments were $2.5 \times 10^{4} \mathrm{l} / \mathrm{kg}$ for $\mathrm{K}_{\mathrm{d} 137 \mathrm{Cs}}$ and $4.4 \times 10^{2} \mathrm{l} / \mathrm{kg}$ for $\mathrm{K}_{\mathrm{d} 90 \mathrm{Sr}}$. Mean values of the concentration factor in fish were $217 \mathrm{l} / \mathrm{kg}$ for $\mathrm{CF}_{137 \mathrm{Cs}}$ and $130 \mathrm{l} / \mathrm{kg}$ for $\mathrm{CF}_{90 S \mathrm{~S}}$, and in reed $60.7 \mathrm{l} / \mathrm{kg}$ for $\mathrm{CF}_{137 \mathrm{Cs}}$ and $17.7 \mathrm{l} / \mathrm{kg}$ for $\mathrm{CF}_{90 \mathrm{~s} r}$. Concentrations of ${ }^{3} \mathrm{H}$ in river sites not affected by Temelín plant were slowly decreasing and their values were substantially below those from the sites affected by the plant.

The data on annual discharges of ${ }^{137} \mathrm{Cs},{ }^{90} \mathrm{Sr}$ and ${ }^{3} \mathrm{H}$ at unaffected (reference) and affected river sites were compared with the data provided by Czech Power Works, Temelín Power Plant on discharges of ${ }^{3} \mathrm{H}$ and other AAFP. The results of a balance assessment of the radionuclides discharged in the Vltava River at Hněvkoviceand the Lužnice River at Koloděje in the period 1990-2013 showed that the background activities were relevant to $2.50 \mathrm{GBq} / \mathrm{y}$ for ${ }^{137} \mathrm{Cs}$, $8.03 \mathrm{GBq} / \mathrm{y}$ for ${ }^{90} \mathrm{Sr}$ and $1.84 \mathrm{TBq} / \mathrm{y}$ for ${ }^{3} \mathrm{H}$. In the period 2002-2013, the Temelín plant discharged annually $39 \mathrm{TBq} / \mathrm{y}$ of tritium while maximum annual discharges of other AAFP did not exceed 0.5 $\mathrm{GBq} / \mathrm{y}$. The background activities of ${ }^{137} \mathrm{Cs}$ and ${ }^{90} \mathrm{Sr}$ presently exceed substantially other AAFP discharged from the Temelín plant. In the period 2002-2013, the quantity of ${ }^{3} \mathrm{H}$ discharged in the Vltava River at Hladná was in average $35.5 \mathrm{TBq} / \mathrm{y}$. In terms of ${ }^{3} \mathrm{H}$, the impact of the waste water discharges from the Temelín plant was there-

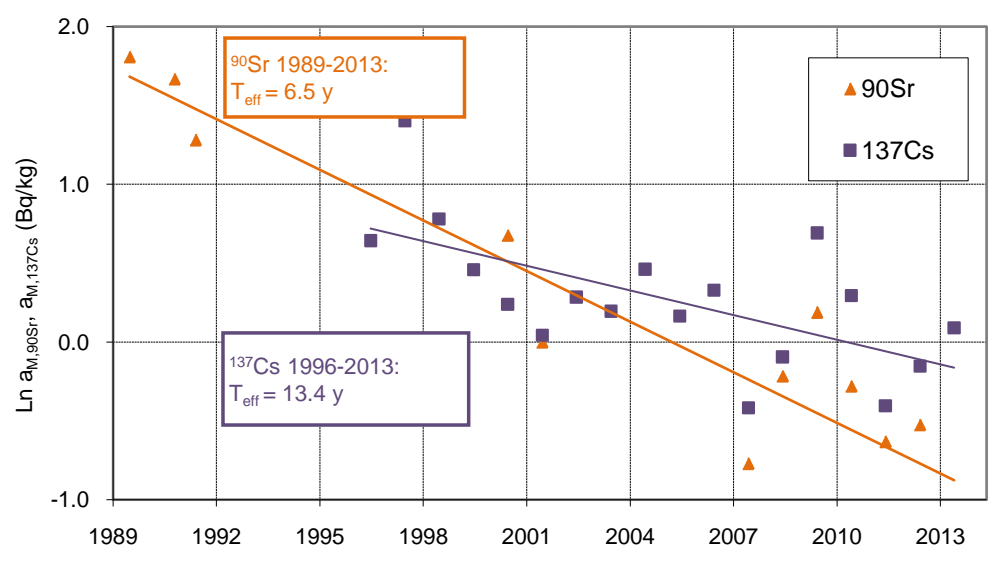

Figure 6. Time changes in annual average concentrations of ${ }^{137} \mathrm{Cs}$ and ${ }^{90} \mathrm{Sr}$ in aquatic plants (dry matter). 
fore substantiated.

\section{Acknowledgements}

This paper was prepared with the support of the project Czech Electric Company No. 90002551.

\section{References}

[1] Outola, I., Saxén, R. and Heinävaara, L. (2009) Transfer of ${ }^{90} \mathrm{Sr}$ into Fish in Finnish Lakes. Journal of Environmental Radioactivity, 100, 657-664. http://dx.doi.org/10.1016/j.jenvrad.2009.05.004

[2] Hanslík, E., Jedináková-Kř́ížová, V., Ivanovová, D., Kalinová, E., Sedlářová, B. and Šimonek, P. (2005) Observed Half-Lives of ${ }^{3} \mathrm{H},{ }^{90} \mathrm{Sr}$ and ${ }^{137} \mathrm{Cs}$ in Hydrosphere in the Vltava River Basin (Bohemia). Journal of Environmental Radioactivity, 81, 307-320. http://dx.doi.org/10.1016/j.jenvrad.2004.01.042

[3] Hanslík, E., Ivanovová, D., Jedináková-Křřžová, V., Juranová, E. and Šimonek, P. (2009) Concentration of Radionuclides in Hydrosphere Affected by Temelín Nuclear Power Plant in Czech Republic. Journal of Environmental Radioactivity, 100, 558-563. http://dx.doi.org/10.1016/j.jenvrad.2009.03.020

[4] Ivanovová, D. and Hanslík, E. (2009) Bioaccumulation of ${ }^{137}$ Cs in fish in Orlík reservoir (South Bohemia) during the period 1990-2007. In: Szilágyi, M. and Szentmihályi, K., Eds., Trace Elements in the Food Chain Vol. 3. Deficiency or Excess of Trace Elements in the Environment as a Risk of Health, Working Committee on Trace Elements of the Hungarian Academy of Sciences (HAS), Institute of Materials and Environmental Chemistry of the HAS, 177-181.

[5] Hanslík, E. and Ivanovová, D. (2010) Impact of Radionuclide Discharges from Temelín Nuclear Power Plant on the Vltava River (Czech Republic). In: Tsvetkov, P., Ed., Nulear Power, Indie, Sciyo, 311-336.

[6] Ivanovová, D. and Hanslík, E. (2010) Temporal and Spatial Changes in Tritium Concentration in the Vltava River Basin Affected by the Operation of Temelín Nuclear Power Plant. Acta Universitatis Carolinae Environmentalica, 1-2, 17-31.

[7] Hanslík, E., Marešová, D. and Juranová, E. (2013) Radioactive Background in Hydrosphere Prior to Planned Extension of Nuclear Power Plant. International Journal of Nuclear Energy Science and Engineering, 3, 47-55.

[8] Hanslík, E., Marešová, D. and Juranová, E. (2013) Temporal and Spatial Changes in Radiocaesium and Radiostrontium Concentrations in the Vltava River Basin Affected by the Operation of Temelín Nuclear Power Plant. European Journal of Environmental Sciences, 3, 5-16.

[9] ČSN ISO 10703 (75 7630) (2008) Water Quality, Determination of the Activity Concentration of Radionuclides by High Resolution Gamma-Ray Spectrometry. Czech Standard Institute. (In Czech)

[10] Hanslík, E. (1993) Determination of Sr-90 and Y-90. In: Čapková, A., Ed., Guide for Water Quality Determination, Ministry of Environment of the Czech Republic, Prague.

[11] ČSN ISO 9698 (75 7635) (2011) Water Quality, Determination of Tritium Activity Concentration, Liquid Scintillation Counting Method, Czech Standard Institute. (In Czech)

[12] Putyrskaya, V., Klemt, E. and Röllin, S. (2009) Migration of ${ }^{137}$ Cs in Tributaries, Lake Water and Sediments of Lago Maggiore (Italy, Switzerland)-Analysis and Comparison with Lago di Lugano and Other Lakes. Journal of Environmental Radioactivity, 100, 35-48. http://dx.doi.org/10.1016/j.jenvrad.2008.10.005

[13] Smith, J.T., Clarke, R.T. and Saxén, R. (2000) Time-Dependent Behaviour of Radiocaesium: A New Method to Compare the Mobility of Weapons Test and Chernobyl Derived Fallout. Journal of Environmental Radioactivity, 49, 65-83. http://dx.doi.org/10.1016/S0265-931X(99)00088-0

[14] IAEA (2005) Environmental Consequences of the Chernobyl Accident and Their Remediation: Twenty Years of Experience. Report of the UN Chernobyl Forum Expert Group “Environment” (EGE). http://www-ns.iaea.org/downloads/rw/meetings/environ-consequences-report-wm-08.05.pdf

[15] Erlinger, Ch., Ettner, H., Hubmer, A., Hofmann, W. and Steinhäusler, F. (2009) Determination of ${ }^{137}$ Cs in the Water System of a Pre-Alpine Lake. Journal of Environmental Radioactivity, 100, 354-360. http://dx.doi.org/10.1016/j.jenvrad.2009.01.002

[16] Saxén, R. and Ilus, E. (2001) Discharge of ${ }^{137} \mathrm{Cs}$ and ${ }^{90} \mathrm{Sr}$ by Finish Rivers to the Baltic Sea in 1986-1996. Journal of Environmental Radioactivity, 54, 275-291. http://dx.doi.org/10.1016/S0265-931X(00)00154-5

[17] Fechtnerová, M. (2002-2006) Annual Report about Environment 2001-2005. CEZ Group, Temelín. (In Czech)

[18] Lysáček, F. (2007-2014) Annual Report about Environment 2006-2013. CEZ Group, Temelín. (In Czech)

[19] Hanslík, E., Marešová, D. and Juranová, E. (2014) Natural and Artificial Radionuclides in River Bottom Sediments and Suspended Matter in the Czech Republic in the Period 2000-2010. Journal of Environmental Protection, 5, 114119. http://dx.doi.org/10.4236/jep.2014.52015 
[20] Smith, J.T. and Beresford, N.A. (2005) Chernobyl—Catastrophe and Consequences. Praxis Publishing Ltd., Chichester.

[21] IAEA (2010) Handbook of Parameter Values for the Prediction of Radionuclide Transfer in Terrestrial and Freshwater Environments. Technical Reports Series No. 472, IAEA, Vienna. http://www-pub.iaea.org/MTCD/publications/PDF/trs472 web.pdf

[22] Smith, J.T, Kudelsky, A.V., Ryabov, I.N. and Hadderingh, R.H. (2000) Radiocaesium Concentration Factors of Chernobyl-Contaminated Fish: A Study of the Influence of Potassium, and "Blind" Testing of a Previously Developed Model. Journal of Environmental Radioactivity, 48, 359-369. http://dx.doi.org/10.1016/S0265-931X(99)00089-2

[23] Franić, Z. and Marović, G. (2007) Long-Term Investigations of Radiocaesium Activity Concentrations in Carp in North Croatia after the Chernobyl Accident. Journal of Environmental Radioactivity, 94, 75-85.

http://dx.doi.org/10.1016/j.jenvrad.2007.01.001 